\title{
Review
}

\section{Wetlands and invertebrate disease hosts: Are we asking for trouble?}

\author{
HL Malan ${ }^{1 *}$, CC Appleton ${ }^{2}$, JA Day ${ }^{1}$ and J Dini ${ }^{3}$ \\ ${ }^{1}$ Freshwater Research Unit, Dept. of Zoology, University of Cape Town, Rondebosch, Cape Town 7701, South Africa \\ ${ }^{2}$ School of Biological \& Conservation Sciences, University of KwaZulu-Natal, Westville Campus, Durban 4000, South Africa \\ ${ }^{3}$ South African National Biodiversity Institute, Brummeria, Pretoria 0001, South Africa
}

\begin{abstract}
Wetlands provide a range of benefits to society, and yet in South Africa wetlands continue to be affected by human activities. Considerable effort is now being directed towards rehabilitation of degraded wetlands and the construction of artificial systems to treat effluent and stormwater. At the same time, wetlands provide potential habitat for vectors or intermediate hosts (collectively referred to in this document as 'invertebrate disease hosts': IDHs), of parasites implicated in the transmission of such important diseases as malaria and schistosomiasis (bilharzia). The present review considers, for the 2 major IDHs (mosquitoes and schistosome-transmitting snails), the type of habitat required by the water-dependent life stage and the ways in which wetland degradation, rehabilitation and creation may affect the availability of suitable habitat. General practical measures for minimising pest species, particularly mosquitoes, are included. This review also highlights other issues that require research and testing in the South African context, including: the IDHs implicated in less well-known diseases (both of humans and animals) and the control of mosquitoes and schistosome-transmitting snails through biomanipulation. We conclude that in regions of the country where the diseases are prevalent there is the likelihood that wetland rehabilitation and creation could inadvertently encourage the IDHs responsible for transmitting malaria and schistosomiasis. Assessment of the potential risks and benefits of a proposed wetland modification needs to be undertaken in a holistic manner using an adaptive framework that recognises the critical need to balance human and environmental health. Possible ways of controlling IDHs both in an environmentally- and socio-friendly manner need to be investigated using a multidisciplinary approach engaging invertebrate biologists, health care officials, wetland scientists and also sociologists and economists.
\end{abstract}

Keywords: vectors, malaria, Anopheles arabiensis, Anopheles funestus, mosquitoes, schistosomiasis, bilharzia, Bulinus africanus, Bulinus globosus, wetland rehabilitation, wetland creation, wetland degradation

\section{Introduction}

In the past few decades, the importance of wetlands and the benefits they provide to society have gradually become acknowledged. The 'goods and services' supplied by these aquatic ecosystems range from flood control, to water quality amelioration, to provision of fish and building materials (Maltby et al.,1994; Kotze et al., 2008a). Yet in South Africa, as globally, wetlands continue to be affected by human activities. Considerable effort and money is now being directed towards rehabilitation of degraded wetlands. This is evidenced by the activities of the highly successful Expanded Public Works Programme Working for Wetlands which targeted 91 South African wetlands for rehabilitation in 2007/2008 alone, employing nearly 2000 previouslydisadvantaged individuals to do so. Furthermore, the construction of artificial wetlands to treat and polish effluents and stormwater is becoming increasingly popular (Kadlec and Knight, 1996; Walton, 2003), since this technology is environmentally-friendly and cost-effective and therefore accessible to developing countries (Kengne et al., 2003).

\footnotetext{
* To whom all correspondence should be addressed.

前 +2721650 3872; fax: +27216503301 ; e-mail: heather.malan@uct.ac.za

Received 6 February 2009; accepted in revised form 25 August 2009.
}

At the same time, wetlands provide potential habitat for vectors or intermediate hosts (collectively referred to in this document as 'invertebrate disease hosts': IDHs) of parasites causing diseases of major importance to humans and their stock animals (Zimmerman, 2001). The various IDHs under consideration are dependent for all, or at least part, of their life-cycles on water, including freshwater ecosystems such as rivers or wetlands. They have been implicated in the transmission of such diseases as malaria (Miller et al., 2007), schistosomiasis (bilharzia) (Boelee and Laamrani, 2004), filariasis (including river blindness: Davies and Day, 1998), fascioliasis (Appleton et al., 1995) and several arbovirus (arthropod-borne virus) diseases such as Rift Valley fever and West Nile (Matthews and Brand, 2004; Jupp, 2005; WHO, 2008a; b). Many of these diseases are of special importance in Africa. It is a sobering fact that malaria (transmitted by the females of various species of Anopheles mosquitoes), is responsible for the death of between 1.5 and $2.7 \mathrm{~m}$. people in sub-Saharan Africa every year. The disease causes untold hardship and represents a severe burden for emerging economies (Keiser et al., 2005). Bilharzia (more correctly known as schistosomiasis), on the other hand, is carried by various species of aquatic pulmonate snails (Brown, 1994) and kills approximately 200000 people annually in sub-Saharan Africa (WHO, 2002). The number of people infected with either urinary or intestinal schistosomiasis, or both, in South Africa is estimated to be between 
3 and $4 \mathrm{~m}$ (Moodley et al., 2003). Mortality estimates are unavailable but are likely to be low. Morbidity is, however, often severe (Cooppan et al., 1987).

Thus there exists a paradox: whilst wetlands are important in providing many benefits to society, they can also be a source of organisms carrying devastating diseases. Willott (2004) severely criticised the lack of awareness and concern by wetland scientists, claiming that '.. primary texts in conservation biology and the majority of research papers addressing restoration and wetland construction generally do not acknowledge that mosquitoes create practical implementation problems and also problems for the theoretical case for restoration...' In a recent review of wetlands and mosquitoes, Dale and Knight (2008) note a paucity of literature that considers both the values of wetlands and the costs resulting from the presence of mosquitoes. Perhaps to address some of these deficiencies, a review by the Scientific and Technical Review Panel of the Ramsar Convention on Wetlands examined the relationship between wetlands and human health (Ramsar, 2008a).

In light of the seriousness of some of the diseases involved, the increasing focus on wetland rehabilitation and creation, and the ongoing degradation of wetlands, it is important that this matter be investigated with regard to the situation in South Africa. The following questions (amongst others) need to be asked:

- Is there a difference in the number of IDHs in pristine wetlands compared to impacted ones?

- How can artificial wetlands be constructed in a way that minimizes IDH habitat?

- Is it possible to manage wetlands so as to avoid the propagation of nuisance species and at the same time maximise the ecosystem services wetlands provide?

- If not, is it ethical to create or restore habitat for IDHs in areas that could potentially give rise to serious illnesses?

\section{The scope of this review}

Wetlands are diverse ecosystems that range from permanent to temporary systems, inundated or saturated, with water that is static or flowing, fresh or saline (Ramsar, 1971). In the present paper we concentrate on wetlands that are characterised primarily by areas of standing, non-saline water with emergent vegetation. Relevant information has also been drawn from other water bodies, both natural (rivers, salt marshes, lakes) and artificial (reservoirs, irrigation canals, constructed wetlands). Furthermore, only diseases that affect humans are considered here, although diseases that affect animals (both 'stock' and 'domestic') also need investigation. The review is limited primarily to IDHs that have been recorded in South Africa. To a lesser extent, those that occur in South Africa's neighbours are also considered, since one of the effects of climate change is the potential globally for diseases to change their distribution ranges (Poff et al., 2002; Mathews and Brand, 2004; Ramsar, 2008a).

The topic of Southern African wetlands and water-related parasitic diseases of humans was reviewed by Appleton (1983) and Appleton et al. (1995). The present review aims to build on this work by considering, for each of the major IDHs in South Africa, the type of habitat required by the water-dependent life stage, and the ways in which wetland degradation, rehabilitation and creation may affect the availability of suitable habitat. This is followed by some general practical measures for minimising pest species, particularly mosquitoes.

\section{The major diseases and their invertebrate hosts}

Only a brief outline is presented here of the diseases considered and their invertebrate hosts. Descriptions of the life-cycles of the parasites involved and their transmission routes are given for malaria, schistosomiasis, fascioliasis and other diseases in most medical parasitology textbooks and invertebrate texts.

Table 1 lists the major disease-causing organisms, together with their invertebrate hosts, that are linked to wetlands in Africa. It is interesting to note that, in addition to malaria, mosquitoes are the vectors of pathogens causing several other serious diseases. According to Jupp (2005), 22 mosquito-borne viruses have been isolated in Southern Africa, and of these 10 are known to be human pathogens. Four of them (chikungunya, sindbis, West Nile and Rift Valley fever) cause serious illness. One of the most pathogenic arboviruses, dengue, is not endemic to Southern Africa although it is spreading elsewhere in the world. While Aedes aegypti from KwaZulu-Natal are competent vectors of this disease (Jupp, 2005), its failure to become established is attributable to several factors:

- The number of introduced infections is too low

- The monkey populations available to serve as reservoir hosts are too fragmented

- Infected vervet monkeys (i.e. non-macaques) are likely to die of the disease (Swanepoel and Kemp, 2005).

Of the diseases listed, malaria and schistosomiasis are currently the most important from the point of view of human health and are discussed further in this review. Others, such as fascioliasis and several of the arboviruses may pose a threat, but at this stage little is known about their prevalence (Appleton et al., 1995; Jupp, 2005) and they require further investigation.

\section{Malaria}

Malaria has a long history of association with wetlands. The name was coined in 1690 by physician Francesco Torti from the Italian 'mal aria' or bad air - an allusion to the belief that noxious marsh gases caused the deadly disease (Langone, 2008). Today it is known that the disease is caused by Plasmodium parasites transmitted by various species of female Anopheles mosquitoes. More than $90 \%$ of the malaria cases in South Africa are caused by Plasmodium falciparum, the species that results in the most serious complication, cerebral malaria (Durrheim et al., 2001). Although globally there are many mosquito species, only a few are of concern as vectors of disease; furthermore, the species in a region vary geographically and temporally (Russell, 1999). In South Africa malaria is endemic to parts of Limpopo Province, Mpumalanga and northern KwaZulu-Natal and also occurs in eastern Swaziland (Jupp, 2005). The most important vector of malaria in South Africa is Anopheles arabiensis (Appleton et al., 1995; Maharaj, 2003). Anopheles funestus and An. gambiae sensu stricto (s.s.) also occur in South Africa but are currently of less importance in transmitting the disease than is An. arabiensis. The situation is made more difficult by the fact that the mosquito vectors involved belong to complexes, each of which consist of several species that cannot be separated by morphology but only by laboratory techniques that distinguish them genetically. Identification to species level is important, since different species of the same complex, found in the same geographical regions, may have different environmental preferences and different degrees of vector competency, and thus vary in their 


\begin{tabular}{|c|c|c|c|c|c|}
\hline \multicolumn{6}{|c|}{$\begin{array}{cc}\text { The major diseases, with their invertebrate hos } 1 \\
\end{array}$} \\
\hline Disease & $\begin{array}{l}\text { Parasite causing } \\
\text { the disease }\end{array}$ & Invertebrate host & $\begin{array}{l}\text { Geographical } \\
\text { distribution }\end{array}$ & Comments & Reference \\
\hline Malaria & \begin{tabular}{|l|} 
Plasmodium spp. \\
In South Africa: \\
P. falciparum $(90 \%$ of \\
cases)
\end{tabular} & $\begin{array}{l}\text { Anopheline mosquitoes. } \\
\text { In South Africa: } \\
\text { An. arabiensis } \\
\text { An. gambiae } \\
\text { An. funestus } \\
\end{array}$ & $\begin{array}{l}\text { Most of Africa, includ- } \\
\text { ing Southern Africa, } \\
\text { N. KZN, Limpopo, } \\
\text { Mpumalanga }\end{array}$ & $\begin{array}{l}\text { An. arabiensis and } \\
\text { An. gambiae are mor- } \\
\text { phologically identical }\end{array}$ & $\begin{array}{l}\text { Tren and Bate, 2004; } \\
\text { Davies and Day, 1998; } \\
\text { Appleton et al., } 1995\end{array}$ \\
\hline $\begin{array}{l}\text { Schistosomiasis } \\
\text { (bilharzia) }\end{array}$ & $\begin{array}{l}\text { Schistosoma spp. } \\
\text { In South Africa: } \\
\text { S. haematobium } \\
\text { S. mansoni }\end{array}$ & $\begin{array}{l}\text { In South Africa: } \\
\text { Bulinus globosus \& B. } \\
\text { africanus } \\
\text { Biomphalaria pfeifferi }\end{array}$ & $\begin{array}{l}\text { Most of Africa, includ- } \\
\text { ing Southern Africa, } \\
\text { N. KZN, Limpopo, } \\
\text { Mpumalanga }\end{array}$ & $\begin{array}{l}\text { S. haematobium causes } \\
\text { urinary bilharzia. } \\
\text { S. mansoni causes } \\
\text { intestinal bilharzia }\end{array}$ & $\begin{array}{l}\text { Davies and Day, 1998; } \\
\text { Appleton et al., } 1995\end{array}$ \\
\hline $\begin{array}{l}\text { Fascioliasis } \\
\text { (liver fluke) }\end{array}$ & \begin{tabular}{|l} 
Fasciola hepatica \\
Fasciola gigantica \\
Both of above species
\end{tabular} & $\begin{array}{l}\text { Lymnaea truncatula } \\
\text { L. natalensis } \\
\text { L. columella (an exotic } \\
\text { species) }\end{array}$ & $\begin{array}{l}\text { Some parts of Africa, } \\
\text { especially Egypt. } \\
\text { Reported to occur in } \\
\text { South Africa but extent } \\
\text { unclear. }\end{array}$ & $\begin{array}{l}\text { Human infection is not } \\
\text { common, but is increas- } \\
\text { ing worldwide }\end{array}$ & $\begin{array}{l}\text { Appleton et al., 1995; } \\
\text { Quayle and Appleton, } \\
2008\end{array}$ \\
\hline $\begin{array}{l}\text { Paragonimiasis } \\
\text { (lung fluke) }\end{array}$ & $\begin{array}{l}\text { Possibly, } \\
\text { Paragonimus } \\
\text { kellicotti }\end{array}$ & $\begin{array}{l}\text { Host species not } \\
\text { definitively identified in } \\
\text { South Africa. Snail host } \\
\text { followed by a crusta- } \\
\text { cean host. } \\
\end{array}$ & $\begin{array}{l}\text { Only a few reports from } \\
\text { South Africa. }\end{array}$ & $\begin{array}{l}\text { Transmission to } \\
\text { humans through eating } \\
\text { insufficiently-cooked } \\
\text { freshwater crustaceans. }\end{array}$ & $\begin{array}{l}\text { Appleton et al., 1995; } \\
\text { CDC 2008a }\end{array}$ \\
\hline $\begin{array}{l}\text { Rift Valley } \\
\text { Fever }\end{array}$ & an "arbovirus" & $\begin{array}{l}\text { Mosquitoes (several } \\
\text { spp. including Aedes } \\
\text { spp.) }\end{array}$ & \begin{tabular}{|l|} 
Central and Northern \\
Africa. Parts of \\
Southern Africa. \\
Sporadic cases in South \\
Africa \\
\end{tabular} & $\begin{array}{l}\text { Zoonosis - usually } \\
\text { infects cattle, goats, } \\
\text { sheep, buffalo }\end{array}$ & $\begin{array}{l}\text { WHO 2007; } \\
\text { McIntosh et al., 1980; } \\
\text { Jupp, } 2005\end{array}$ \\
\hline $\begin{array}{l}\text { West Nile and } \\
\text { Sindbis Fever }\end{array}$ & "arboviruses" & $\begin{array}{l}\text { Mosquitoes: Culex } \\
\text { univittatus \& } C \text {. neavei }\end{array}$ & $\begin{array}{l}\text { Central Africa. } \\
\text { Occasionally in South } \\
\text { Africa. }\end{array}$ & $\begin{array}{l}\text { Zoonoses. Birds }= \\
\text { reservoir host. The } \\
\text { ecology of the } 2 \text { dis- } \\
\text { eases is very similar in } \\
\text { South Africa. } \\
\end{array}$ & $\begin{array}{l}\text { Rappole et al., 2000; } \\
\text { Willot, 2004; } \\
\text { Jupp, } 2005\end{array}$ \\
\hline Chikungunya & an "'arbovirus” & $\begin{array}{l}\text { Mosquitoes (Aedes } \\
\text { aegypti and other Aedes } \\
\text { spp.) }\end{array}$ & $\begin{array}{l}\text { West, central and } \\
\text { Southern Africa, Asia. } \\
\text { Occasionally in South } \\
\text { Africa. }\end{array}$ & $\begin{array}{l}\text { Zoonosis - usually } \\
\text { infects monkeys \& } \\
\text { baboons }\end{array}$ & $\begin{array}{l}\text { WHO, 2008b; } \\
\text { Jupp, } 2005\end{array}$ \\
\hline Dengue & an 'arbovirus' & Mosquitoes (A. aegypti) & $\begin{array}{l}\text { Most tropical and sub- } \\
\text { tropical areas of world. } \\
\text { Not in South Africa, but } \\
\text { present in Mozambique. }\end{array}$ & $\begin{array}{l}\text { Increasing global } \\
\text { threat. Potential to be } \\
\text { imported from Asia. }\end{array}$ & $\begin{array}{l}\text { WHO, 2008a; } \\
\text { CDC, 2008b; } \\
\text { Jupp, 2005; } \\
\text { Waner, 1999 } \\
\end{array}$ \\
\hline Yellow fever & an 'arbovirus' & $\begin{array}{l}\text { Mosquitoes (Aedes } \\
\text { simpsaloni, } A \text {. africa- } \\
\text { nus, } A . \text { aegypti) }\end{array}$ & $\begin{array}{l}\text { Central Africa (not } \\
\text { Southern or South } \\
\text { Africa) }\end{array}$ & $\begin{array}{l}\text { Rare form is a } \\
\text { Zoonosis. Primates = } \\
\text { reservoir host. Urban } \\
\text { form is most common. }\end{array}$ & $\begin{array}{l}\text { CDC, 2007; } \\
\text { WHO, } 2001\end{array}$ \\
\hline $\begin{array}{l}\text { Filariasis } \\
\text { (elephantiasis) }\end{array}$ & $\begin{array}{l}\text { Nematodes: } \\
\text { Wuchereria bancrofti } \\
\text { Onchocerca volvulus }\end{array}$ & Culex spp. mosquitoes & $\begin{array}{l}\text { Central Africa (not } \\
\text { Southern or South } \\
\text { Africa) }\end{array}$ & & Davies and Day, 1998 \\
\hline $\begin{array}{l}\text { Onchocerciasis } \\
\text { (River } \\
\text { blindness) } \\
\end{array}$ & $\begin{array}{l}\text { Nematode: } \\
\text { Onchocerca volvulus }\end{array}$ & $\begin{array}{l}\text { Black flies (Simulium } \\
\text { damnosum) }\end{array}$ & $\begin{array}{l}\text { Central Africa (not } \\
\text { Southern or South } \\
\text { Africa) }\end{array}$ & $\begin{array}{l}\text { Found near rapidly- } \\
\text { flowing rivers. Can also } \\
\text { lead to elephantiasis. } \\
\end{array}$ & Davies and Day, 1998 \\
\hline $\begin{array}{l}\text { Dracunculiasis } \\
\text { (Guinea worm) }\end{array}$ & $\begin{array}{l}\text { Nematode: } \\
\text { Dracunculus } \\
\text { medinensis }\end{array}$ & Copepods (Cyclops sp.) & $\begin{array}{l}\text { Central Africa, (not } \\
\text { Southern or South } \\
\text { Africa) }\end{array}$ & & Davies and Day, 1998 \\
\hline
\end{tabular}

ability to transmit malaria. Anopheles arabiensis, the most important malarial vector in South Africa and elsewhere in Africa, belongs to the complex An. gambiae sensu lato (s.1.). Two other vector species that are grouped within this complex have been known to occur in South Africa: An. gambiae s.s. and An. merus. Anopheles funestus s.s., on the other hand, belongs to the An. funestus s.l. complex. No other members of this complex are considered to be important in the transmission of malaria. It would seem, however, that An. gambiae s.s. and An. funestus were both eradicated from South Africa through the indoor DDT spraying programme by the 1980s (although see below).

Malaria in Africa is on the increase (WHO and UNICEF, 2003). In South Africa the period 1996 to 2000 saw an alarming increase in the number of reported cases of malaria with associated deaths rising from fewer than 50 per year to more than 450 which necessitated the limited, but still controversial, reintroduction of indoor spraying with the insecticide DDT (Attaran and Maharaj, 2000; Tren and Bate, 2004; Wells and Leonard, 2006). The mortality rate due to malaria has 
since returned to less than 50 per year and has stabilised at that level (DOH, 2008). This epidemic was at least partly due to the reintroduction of An. funestus. There is a high probability that this species has again been eradicated from South Africa, although it still occurs in southern Mozambique (Maharaj et al., 2005; Wells and Leonard, 2006). Thus, there is an ever-present threat of resurgence due to the re-entry of An. funestus and the development of resistance - both by the parasite to anti-malarial drugs and by the vector to insecticides (WHO and UNICEF, 2006). The influx of infected refugees across South Africa's borders from countries such as Zimbabwe and Mozambique, where malarial control programmes are weak (Tren and Bate, 2004), increased travel by South Africans into malarial-infested areas (Durrheim et al., 2001), and the possible spread of the disease beyond its current limits due to global climate change (Tanser et al., 2003; DEAT, 2006) are factors that may potentially contribute to increased malarial transmission in this country.

\section{Schistosomiasis}

There are 2 species of schistosomes (or blood flukes) that commonly cause serious human morbidity in South Africa. Schistosoma haematobium causes urinary schistosomiasis, and Schistosoma mansoni causes the intestinal form of the disease. All schistosomes have an obligatory intermediate host, a freshwater snail, in which asexual reproduction takes place, alternating with a human definitive host in which the parasite reproduces sexually. Although compared with malaria it has a low mortality rate in people, schistosomiasis is a chronic, debilitating disease that is especially prevalent in children (Thomas and Tait, 1984; Appleton et al., 1995). It may cause damage to the bladder, liver and intestine, lowers resistance of the host to other diseases, and often results in retarded growth and reduced cognitive development in children (WHO, 2002; Kvalsvig, 2003; WHO and UNICEF, 2006). Schistosomiasis is endemic to the eastern parts of South Africa, mainly the provinces of Limpopo, KwaZulu-Natal and Mpumalanga, where prevalence rates of $60-80 \%$ in schoolchildren from rural areas have been reported (Gear et al., 1980; Wolmarans et al., 2006). Two freshwater snails Bulinus africanus and B. globosus, serve as intermediate hosts for $S$. haematobium. Schistosoma mansoni is less widely distributed than the urinary parasite in South Africa and uses the snail Biomphalaria pfeifferi as its intermediate host.

Both Bulinus africanus and B. globosus belong to the B. africanus group of the genus Bulinus (Brown, 1994). There is, however, debate around the validity of the 2 species as they occur in South Africa, based on anatomical criteria. It is possible, since intermediate forms undoubtedly do exist, that they represent physiological extremes of a single eurythermal species. Comparative temperature studies (Shiff, 1964; Shiff and Garnett, 1967; Joubert et al., 1984; Joubert et al., 1986) have shown that B. globosus is better adapted to warmer conditions than $B$. africanus and this is reflected in the respective geographical ranges of the 2 'species' (Brown, 1966; De Kock and Wolmarans, 2005). In terms of parasitology, both species are susceptible to infection by $S$. haematobium but although the range of $B$. africanus covers most of the endemic area of the country, that of B. globosus covers the area with the highest prevalence.

The genus Biomphalaria belongs to the same family of snails as Bulinus and Biomphalaria pfeifferi is the only species occurring in South Africa (Brown, 1994). As is the case with B. africanus/globosus and the parasite $S$. haematobium, the distribution of B. pfeifferi is wider than that of S. mansoni.

\section{Abiotic and biotic effects of wetland degradation, rehabilitation and creation}

Wetlands in South Africa have been altered mainly by agricultural activities, by the mining sector and by urban development, leading to the loss of more than $50 \%$ of wetlands in some catchments (Kotze et al., 1995). A list of the major impacts, both direct and indirect, that result in wetland loss and degradation, in conjunction with the major associated abiotic or biotic effects, is shown in Table 2.

\begin{tabular}{|c|c|}
\hline \multicolumn{2}{|c|}{$\begin{array}{c}\text { Table } 2 \\
\begin{array}{c}\text { Causes of wetland loss and degradation (adapted from Dugan, } 1990 \text { and Shearer, 1997) and their major } \\
\text { potential abiotic and biotic effects }\end{array}\end{array}$} \\
\hline Direct impacts & Potential effects \\
\hline Drainage for agriculture, forestry, mosquito control & Reduction in inundated/saturated area \\
\hline Dredging for navigation, flood control & $\begin{array}{l}\text { Reduction in inundated/saturated area due to increased } \\
\text { through-flow }\end{array}$ \\
\hline $\begin{array}{l}\text { Filling for solid waste disposal, road construction, residential, } \\
\text { commercial and industrial development }\end{array}$ & Reduction in inundated/saturated area \\
\hline Erosion & $\begin{array}{l}\text { Reduction in inundated/saturated area (due to formation of } \\
\text { drainage gullies) }\end{array}$ \\
\hline Groundwater abstraction & Reduction in inundated/saturated area \\
\hline Flooding due to construction of dams & Increase in area of inundated habitat \\
\hline $\begin{array}{l}\text { Mining of wetland soils for peat, coal, gravel, phosphate, salts } \\
\text { and other materials }\end{array}$ & $\begin{array}{l}\text { Changes in water quality, infilling, creation of areas of standing } \\
\text { water (e.g. borrow pits) }\end{array}$ \\
\hline $\begin{array}{l}\text { Discharge of pollutants from point-sources, diffuse sources } \\
\text { (agriculture, informal settlements, urban areas), air pollution }\end{array}$ & $\begin{array}{l}\text { Changes in water quality, impacts on biota and creation of areas } \\
\text { of standing water }\end{array}$ \\
\hline Poorly managed grazing, mowing and burning & Changes in vegetation composition and structure \\
\hline \multicolumn{2}{|l|}{ Indirect impacts } \\
\hline Sediment diversion by dams, channels and other structures & $\begin{array}{l}\text { Drainage of wetland due to erosion channels forming. } \\
\text { Reduction in inundated/saturated areas. }\end{array}$ \\
\hline Hydrological alterations by canals, roads and other structures & Draining or creation of areas of standing water \\
\hline Subsidence due to extraction of groundwater, oil, minerals & Formation of areas of standing water \\
\hline
\end{tabular}


As can be seen from Table 2, a wide range of impacts occur in wetlands. The major abiotic effects include changes to wetland hydrology, frequently reducing wetland extent through deliberate draining, or the inadvertent formation of erosion gullies, which leads to reduced water retention. In some cases there is an increase in the extent of inundated areas due to the construction of weirs, berms or roads, or the creation of borrow pits. Water quality can be impaired due to pollution and direct impacts to the vegetation can be brought about by agricultural activities, burning and overgrazing. Only the major effects are noted in Table 2, but ancillary effects are also likely. For example, the discharge of effluents into a wetland may, in addition to changing water quality, have an effect on the biota.

It follows from the discussion above that rehabilitation of wetlands also encompasses a range of remedial activities that includes restoration of indigenous vegetation and removal of alien plants (and sometimes animals), reproducing natural processes and restoring the physical characteristics of the system (Duffield and Hill, 2002). From an analysis of the projects undertaken by Working for Wetlands, Kotze et al. (2008b) found that, in essence, the focus of rehabilitation interventions was to achieve one or more of 3 broad objectives: raising the water table, reinstating a more diffuse pattern of surface water flow, and stabilising eroding areas. The first 2 , by altering the hydraulic habitat, may increase the extent of habitat available for IDHs. Russell (1999) noted that in regard to mosquitoborne pathogens, the severity of disease is usually related to the number of adult mosquito vectors, which in turn, is related to the availability of suitable breeding sites. Another common rehabilitation activity is removal of alien plants. Alteration of the vegetation in a wetland can have implications for control of IDHs, as described later. Furthermore, changes in water quality may also encourage IDHs if this leads to a more favourable environment. In short, with regard to IDH populations the consequences of wetland degradation, rehabilitation or creation will depend on the specific environmental requirements of the aquatic life stage, be it of a mosquito or a schistosome-carrying snail, as discussed in the next section.

\section{Habitat requirements of the invertebrate disease hosts}

The environmental requirements of both juveniles and adults differ for different species of IDHs. The snails that are the intermediate hosts of the schistosomiasis parasite require an aquatic habitat for their entire lives (Wolmarans et al., 2005), and are therefore limited in the extent to which they can disperse. Anopheline mosquitoes, on the other hand, require an aquatic habitat only in their immature stages. The adults are highly mobile and can select favourable sites for egg-laying. Table 3 provides a summary of environmental requirements of the larvae of the key IDHs, as gleaned from the literature. According to Walker and Lynch (2007), larval habitat requirements differ not only between different species of the $A n$. gambiae s.l. complex but even between different populations of the same species. Species were included in Table 3 only if reference was made to the particular species (e.g. An. gambiae s.s. and not An. gambiae s.1.).

\section{Aquatic habitat requirements of anopheline larvae}

There are important differences in breeding habitats used by females of the Anopheles gambiae and An. funestus complexes. Site selection and larval behaviour are influenced by several environmental factors (Impoinvil et al., 2008), including distance to human habitation and substrate type. Other important parameters are: the salinity and turbidity of the water, the size and degree of permanence of the water body, the amount of sunlight, the presence of emergent/floating vegetation and shade (Walker and Lynch, 2007). In general, larvae of anopheline mosquitoes, in common with larvae of most other mosquito species, are confined to still waters. This enables the larvae to remain close to the surface with their spiracles and breathing tubes open (Russell, 1999). In comparison to many other species of mosquitoes, anophelines prefer clean rather than polluted water (Walker and Lynch, 2007), although in urban areas in parts of Africa An. gambiae s.l. appears to be adapting to new habitats such as rubbish-filled pools, sometimes containing sewage (Keating et al., 2003; Awolola et al., 2007).

The distribution of members of the An. gambiae complex within the endemic malaria area of South Africa appears to be opportunistic, depending largely on the availability of suitable breeding habitats. As can be seen from Table 3, larvae of the sibling species An. gambiae s.s. and An. arabiensis may be found in aquatic habitats ranging from rice fields, borrow pits and temporary pools to drinking-water vessels, the water collecting in a cows' hoof prints, and even tyre tracks (Le Sueur and Sharp, 1988; Service and Townsend, 2002 cited in Walker and Lynch, 2007). On the Makathini Flats in north-eastern KwaZulu-Natal, one of South Africa's worst malaria areas, rice paddies, rain pools, cattle hoof prints and human footprints are all used by An. arabiensis for breeding, particularly during the transmission season. Natural rain pools and hoof/footprints are used more-or-less equally and constitute the primary breeding habitats for An. arabiensis. The major physical and chemical characteristics of these 3 habitat types are given by Le Sueur and Sharp (1988), Hamer and Appleton (1991) and Appleton et al. (1995).

In general there appears to be little difference in the environmental requirements of the larval stages of An. gambiae s.s. and $A n$. arabiensis, both preferring sunny, temporary puddles or pools rather than permanent systems (Gillies and de Meillon, 1968; Gimnig et al., 2001; Koenraadt et al., 2004; Walker and Lynch, 2007). Adaptation to temporary aquatic habitats is enhanced by the short larval development times and the absence of predators. There are reports of An. gambiae larvae (species not given) surviving on moist and drying mud (Miller et al., 2007) but generally they are intolerant of desiccation. Several studies have observed temporal variation in abundance of the 2 species, however, suggesting that adults of An. arabiensis are better adapted to dry, hot conditions (Lindsay et al., 1998; Gimnig et al., 2001; Koenraadt et al., 2004), whereas An. gambiae s.s. prefers more humid conditions. Due to the temporary nature of the preferred breeding habitats, during the dry season these anopheline species over-winter in perennial water bodies (Appleton et al., 1995) often some distance from the temporary ones to which they spread after the rains have started.

In contrast to the opportunistic habitat preferences of $A n$. arabiensis and An. gambiae s.s., Anopheles funestus chooses permanent, standing water bodies in which to lay eggs. These are typically shaded and have dense vegetation, either floating or emergent (Mendis et al., 2000). The different breeding requirements of An. arabiensis and An. funestus can influence the presence/absence of malaria in an area. For example, the absence of malaria in the narrow 7-8 $\mathrm{km}$ wide strip along the coast of northern KwaZulu-Natal is probably because the local 


\begin{tabular}{|c|c|}
\hline \multicolumn{2}{|c|}{$\begin{array}{c}\text { Table } 3 \\
\text { Habitat requirements of the aquatic life stage for Invertebrate Disease Hosts implicated in malaria and } \\
\text { schistosomiasis }\end{array}$} \\
\hline Invertebrate disease host & Reference \\
\hline \multicolumn{2}{|l|}{ Anopheles arabiensis } \\
\hline $\begin{array}{l}\text { Hydraulic habitat/wetland type: } \\
\text { - Opportunistic. Uses different breeding habitat in summer and winter. In the dry winter season, } \\
\text { oviposition occurs in pools of irrigation seepage water and margins of large permanent pans. In } \\
\text { summer the adults disperse and make use of small temporary water bodies, e.g. hoofprints, tyre } \\
\text { tracks, borrow pits. Rice fields are also an important habitat for An. arabiensis in parts of Africa. } \\
\text { - Pools, paddy and marsh habitat were the most productive larval habitats for An. arabiensis } \\
\text { (Mwangangi et al., 2008) } \\
\text { - Temporary sunlit pools without vegetation, wells and rice fields } \\
\text { The contribution of temporary pools to adult numbers was dependent on the length of time they } \\
\text { held water, with long-lived pools contributing more than the short-lived ones }\end{array}$ & $\begin{array}{l}\text { Le Sueur and Sharp, 1988; } \\
\text { Mendis et al., 2000; } \\
\text { Mutero et al., 2000; } \\
\text { Walker and Lynch, 2007; }\end{array}$ \\
\hline $\begin{array}{l}\text { Predators } \\
\text { - Newly-formed habitats are the most productive aquatic habitats, while old and more perma- } \\
\text { nent habitats are the least productive due to natural regulation of mosquito immatures (due to } \\
\text { predation) } \\
\text { The presence of Dytiscidae, Notonectidae, Belostomatidae and Ephemerillidae negatively } \\
\text { affected the number of emergent mosquitoes }\end{array}$ & Mwangangi et al., 2008; \\
\hline $\begin{array}{l}\text { Water quality } \\
\text { - Both the winter and summer breeding sites of An. arabiensis were totally unshaded or received } \\
\text { partial sunlight } \\
\text { In temporary pools examined by Le Sueur and Sharp (1988) the temperature often exceeded } \\
40^{\circ} \mathrm{C} \text { for some part of the day. An. arabiensis was never recorded at a pH less than 7.0., and } \\
\text { always in water that was totally fresh. } \\
\text { - Dissolved oxygen levels in rain pools were as low as } 5-6 \mathrm{mg} / \ell \text { but sometimes higher (Hamer } \\
\text { and Appleton, 1991). } \\
\text { Turbidity in rain pools ranged from } 140-520 \mathrm{NTU} \text { (Hamer and Appleton, 1991) - i.e. even rela- } \\
\text { tively turbid water was suitable for breeding of this species } \\
\text { In Kenya, An. arabiensis populations increased when ponds were treated with ammonium sul- } \\
\text { phate fertiliser which was postulated to reduce the turbidity of water in rice fields }\end{array}$ & $\begin{array}{l}\text { Le Sueur and Sharp, 1988; } \\
\text { Mutero et al., 2004; } \\
\text { Hamer and Appleton, } \\
\text { 1991; }\end{array}$ \\
\hline $\begin{array}{l}\text { Vegetation } \\
\text { - During the winter, larvae are found within submerged vegetation (e.g. Potamogeton crispus) } \\
\text { which protects larvae from predators } \\
\text { - Found in association with dense macrophyte growth in winter such as Cynodon dactylon, } \\
\text { Ludwigia, Panicum sp. } \\
\text { - During summer temporary pools without vegetation are the preferred habitat for oviposition }\end{array}$ & $\begin{array}{l}\text { Le Sueur and Sharp, } 1988 ; \\
\text { Mutero et al., } 2000 \text { \& } \\
\text { 2004; } \\
\text { Walker and Lynch, } 2007\end{array}$ \\
\hline \multicolumn{2}{|l|}{ Anopheles funestus } \\
\hline $\begin{array}{l}\text { Hydraulic habitat/wetland type: } \\
\text { - } \quad \text { Prefers still water } \\
\text { - Breeds in larger, more permanent pools than An. gambiae complex, e.g. streams, ditches, swamp } \\
\text { margins } \\
\text { - Breeds prolifically in permanent swampy habitats with much vegetation (Mendis et al., 2000) } \\
\text { Mature rice fields provide highly productive breeding habitats for An. funestus in East Africa and } \\
\text { Madagascar, but not in West Africa (Marrama et al., } 1995 \text { cited in Walker \& Lynch, 2007). }\end{array}$ & $\begin{array}{l}\text { Mendis et al., 2000; } \\
\text { Walker and Lynch, 2007; } \\
\text { Minakawa et al., 2002; } \\
\text { Appleton et al., 1995; } \\
\text { Koenraadt et al., 2004; }\end{array}$ \\
\hline $\begin{array}{l}\text { Water quality } \\
\text { - Typically prefers shaded rather than sunny breeding sites }\end{array}$ & Minakawa et al., 2002; \\
\hline $\begin{array}{l}\text { Vegetation } \\
\text { - Breeds prolifically in swampy areas with much floating vegetation, e.g. water hyacinth } \\
\text { - Also amongst emergent vegetation }\end{array}$ & $\begin{array}{l}\text { Mendis et al., 2000; } \\
\text { Gimnig et al., 2001; }\end{array}$ \\
\hline
\end{tabular}

vector, An. funestus, was eliminated through the spraying of DDT (Hargreaves et al., 2000). Furthermore, because the area supported mainly perennial freshwater habitats such as lakes, pans and streams, the other vector species, An. arabiensis, could not survive, and as a result neither could malaria (Le
Sueur, 1993). Current maps of malaria risk in South Africa produced by the Medical Research Council (MRC, 2007) show this strip to be either low or intermediate risk while the Makathini Flats to the west are high risk due to the presence of the Pongolo floodplain and irrigation schemes. 


\section{Hydraulic habitat/wetland type:}

- Production of adult An. gambiae s.s. occurs mainly in small, temporary, pools of water with algae and little or no aquatic vegetation (i.e. the same habitat requirements as An. arabiensis)

- $\quad$ Both An gambiae s.s. and An. arabiensis found sympatrically in ditches and tyre tracks, but slight differences in habitat preference. For An. gambiae s.s.: $82 \%$ found in tyre tracks and $18 \%$ in ditches. For An. arabiensis: $68 \%$ of the larvae were found in tyre tracks and $32 \%$ in ditches (Koenraadt et al., 2004).

Water quality

- The same requirements as An. arabiensis

Gimnig et al., 2001;

Walker and Lynch, 2007;

Mendis, 2000;

Koenraadt et al., 2004;

Gimnig et al., 2001;

Le Seur and Sharp, 1988;

Vegetation

- The same requirements as An. arabiensis

Bulinus africanus/ Bulinus globosus

\section{Hydraulic habitat/wetland type:}

- In the National Freshwater Snail Collection (NFSC), most commonly found in rivers (28\% of samples), streams (25\%) and dams (20\%), but also in ditches, irrigation canals, swamps, pools

- Permanently-inundated conditions

- Standing-water, or slow-flowing water (velocity $<0.3 \mathrm{~m} / \mathrm{s}$ )

\section{Water quality}

- Areas in which the mean annual air temperature ranges from $15^{\circ} \mathrm{C}$ to $25^{\circ} \mathrm{C}$.

- Optimum turbidity $\leq 190 \mathrm{mg} / \ell$

- Optimum conductivity 300-400 $\mathrm{\mu S} / \mathrm{cm}$

- Optimum calcium concentration $5-40 \mathrm{mg} / \ell$

- Optimum bicarbonate concentration $20-200 \mathrm{mg} / \ell$

- Optimum salinity for adults no greater than $3.0 \mathrm{~g} / \ell$; freshwater for juveniles

\section{Substrate}

- Substrate not considered important. In the NFSC, most commonly found on the following substrates; muddy (31\%), stony (25\%), sandy (20\%), plant detritus $(3 \%)$

\section{Vegetation}

- Vegetation was present in $79 \%$ of the NFSC collection sites

\section{Biomphalaria pfeifferi}

\section{Hydraulic habitat/wetland type:}

- In the NFSC, most commonly found in dams (28\% of samples), rivers (27\%), streams (13\%), but also in pans, ditches, irrigation canals, swamps, pools

- $72 \%$ of samples found in perennial water bodies

- $\quad$ Standing-water (49\%) or slow-flowing water $(30 \%)$

Water quality

- Similar to Bulinus africanus/B. globosus

\section{Vegetation}

- Often found in floating mats of Eichhornia (water hyacinth) (Blaber et al., 1984, cited in Appleton et al., 1995)

- Vegetation was present in $73 \%$ of the NFSC collection sites

\section{Habitat requirements of schistosome- transmitting snails}

The habitat requirements of Bulinus africanus, B. globosus and Biomphalaria pfeifferi in South Africa have been fairly well-studied over the past few decades (for example Appleton, 1975; Appleton et al., 1995). Many of the findings from these studies have been confirmed through analysis of the data held in the National Freshwater Snail Collection (NFSC) (De Kock and Wolmarans, 2005) and have recently been summarised by Quayle and Appleton (2008). Consequently, unless indicated otherwise, the information presented below and in Table 3 is from this work. It should be noted that, whilst both $B$. africanus and B. globosus are the intermediate hosts for S. haematobium, on examination of the nearly 3000 samples in the NFSC, De Kock and Wolmarans (2005) found that only roughly 500 samples could be identified as definitely belonging to the first species and 800 to the latter species. The majority of the samples were considered to be from an intermediate population. For that reason the habitat preferences of the B. africanus/globosus group as a whole were identified by De Kock and Wolmarans (2005) and are presented as such in Table 3.

It can be seen from Table 3 that the habitat preferences of all the snail hosts are similar, in that they prefer a 
permanently-inundated aquatic habitat, with slow flowing, or standing water. Bulinus africanus and B. globosus can tolerate some degree of desiccation; however, Biomphalaria pfeifferi is sensitive to drying out. Consequently, these snail species, and in particular B. pfeifferi, are usually found in permanent water bodies. According to Appleton and Stiles (1976) the major environmental factors that influence the distribution of host snails are temperature and current velocity but habitat stability is probably a more accurate parameter. Using records housed in the NFSC, Gear et al. (1980) and De Kock and Wolmarans (2005) showed that B. africanus was distributed from the northern Limpopo Province, Mpumalanga Province and KwaZulu-Natal Province, and down the coastal parts of the Eastern Cape as far as Humansdorp (Kromme River). Bulinus globosus, on the other hand, has a more limited distribution and is found only in the warmer, north-eastern parts of the country southwards to Lake Nhlabane in northern KwaZulu-Natal. While all 3 snail species are tolerant of water with a wide range of chemical conditions (Appleton, 1978), B. africanus, and perhaps other species as well, are able to survive sudden and severe changes in dissolved salt content (Heeg, 1975). The possession of haemoglobin as their respiratory pigment allows them to survive in water with low oxygen concentrations, but where extensive coverage of the surface by floating plants causes the water to become anoxic, or nearly so, they cannot survive (Donnelly and Appleton, 1985) and this can interrupt the transmission of schistosomiasis.

\section{Potential effects of wetland degradation, rehabilitation, and construction, on invertebrate disease hosts}

The potential abiotic and biotic changes brought about by wetland degradation or, conversely, rehabilitation, have been discussed above. These changes will now be examined in the light of possible effects on the IDHs of malaria and schistosomiasis, with particular reference to the habitat required by the aquatic life stages. Since these diseases are prevalent only in some parts of South Africa, predominantly in the northeastern corner of the country and the eastern coastal plain, it is particularly in these areas that activities potentially leading to an increase in IDH-suitable habitat are of concern.

\section{Alteration in the extent of inundated area}

Upsurges in schistosomiasis and malaria in local communities following the modification of aquatic ecosystems and construction of water resource development projects have been well-documented (Chitsulo et al., 2000; Zimmerman, 2001; Millennium Ecosystem Assessment, 2005). An increase in the extent of inundated area, either of an existing natural wetland, or by creation of a new artificial system, is likely to lead to an increase in mosquito populations, particularly if other environmental parameters (e.g. flow, water quality) are favourable. Draining and in-filling of wetlands is a time-honoured method used for controlling mosquito populations. It has led to elimination of the disease, and the enabling of settlement, in many regions of the world, including Italy (Millennium Ecosystem Assessment, 2005) and Louisiana in the USA (Willott, 2004), but was accompanied by an inevitable loss of valuable wetland services. Because of the ability of An. arabiensis (and An. gambiae s.s.) to breed in very small isolated pools during the rainy season, if infilling or draining leads to the formation of such habitats the density of the vectors may increase. The provision of permanent water bodies for the insects to over-winter as larvae would also enhance vector populations.

In the case of the snail hosts involved in transmission of schistosomiasis, these are all obligate freshwater species and draining of wetlands would be expected to eradicate them. But would an increase in inundated area automatically lead to an increase in host snails, and therefore to an increase in prevalence of schistosomiasis in the area? Wolmarans et al. (2005) showed that prediction of schistosomiasis infection levels simply by looking at snail density and habitat availability was speculative. Frequent contact between infected people and the shistosome-infested water resource is necessary to initiate and maintain transmission. Nevertheless, there is a well-documented link between water resource development and enhanced burdens of schistosomiasis in nearby communities (Boelee and Laamrani, 2004; WHO and UNICEF, 2006; Millennium Ecosystem Assessment, 2005). Pretorius et al. (1989) and Ofoezie (2002) investigated the occurrence of snail intermediate hosts of schistosomiasis in South African and Nigerian dams respectively. They concluded that unless urgent steps were taken, the adverse health consequences of dams could be greater than their socio-economic benefits. If environmental conditions are favourable, and if populations of snails are present upstream, then they will colonise the new habitat. The salient point is, however, that in order for the schistosome parasite to complete its life-cycle and proliferate, it is necessary for eggs in the urine or faeces of infected humans to enter the water resource. Free-swimming cercariae which emerge from their snail hosts penetrate the skin of people whilst bathing or washing (Davies and Day, 1998), but swimming is the water contact activity most likely to result in transmission since it involves exposure of large areas of the body for long periods of time (Kvalsvig and Schutte, 1986). Good sanitation and the availability of safe, alternative swimming facilities can be very effective measures for reducing schistosomiasis levels (Appleton et al., 1995). In the case of artificial wetlands created to treat effluent or stormwater, it may be possible to exclude people from these areas. A point worth emphasizing is that it is possible to reduce schistosomiasis transmission simply by manipulating human behaviour, but that it is a lot more difficult to do so with malaria.

\section{Alteration in the extent of saturated areas}

Some activities in wetlands (either impacts or remedial measures) may lead to an increase in the areal extent of soil saturation, rather than of inundation. The snail hosts of schistosomes are unlikely to increase in numbers under these conditions but An. arabiensis, with its propensity for breeding in tiny pools, may well do so. An illustration of this is the localised malaria outbreak in Mamfene on the Makathini Flats, north-east KwaZulu-Natal, in 1987, which was traced to An. arabiensis breeding in the hoofprints of cattle attracted by poorly-managed overflow water from nearby cotton fields and rice paddies (Appleton et al., 1995). Furthermore, other IDHs (Table 1) are likely to have very different habitat requirements from those considered here. For instance several species of Aedes mosquitoes that are implicated in diseases such as dengue, yellow fever and West Nile virus lay their eggs on wet mud (Dale and Knight, 2008). Although these diseases (with the possible exception of isolated cases of West Nile virus) do not currently occur in South Africa, global climate change is likely to significantly alter the distribution patterns of organisms throughout the world (Russell, 1998; Poff et al., 2002). Thus activities that 
lead to incomplete draining of wetland soils may result in the removal of habitat for some IDHs, but create potential habitat for others.

\section{Altering flow pattern}

As noted by Kotze et al. (2008b), one of the major activities of wetland rehabilitation is to reinstate diffuse flow. This increases the retention time of water within the wetland and enhances several key wetland functions such as amelioration of water quality and retention of flood-flows. Table 3 shows that An. arabiensis, An. gambiae and An. funestus all breed in standing water, which facilitates larval respiration and prevents the larvae from being washed away. The snail hosts of schistosomiasis, Bulinus africanus, B. globosus and Biomphalaria pfeifferi also prefer standing or slow-flowing water, and cannot tolerate water velocities greater than $0.3 \mathrm{~m} / \mathrm{s}$ (Appleton et al., 1995). Thus, there is a potential risk of increasing IDH densities under decreased flow conditions. Other factors may also come into play, however, depending on site-specific conditions. For example if the number of predators is also enhanced by reduced flow this could off-set the effects of increased numbers of IDHs resulting from more favourable environmental conditions.

\section{Secondary effects of altered hydraulic conditions}

Altering hydraulic habitat can in turn give rise to secondary effects such as changes in water quality. Aquatic plants and animals may respond directly to altered hydraulic conditions, or indirectly to altered water quality (Malan and Day, 2002). For example, alteration of water depth is likely to change the extent of emergent macrophyte beds. Manipulation of macrophytes, both emergent and floating, has been used in artificial wetlands to minimise mosquitoes and snails (see later). Changing water depth (and flow rate) may also alter water quality in a wetland. Reduced depth and flow rates are likely to result in decreased turbidity, as well as increased temperatures in summer and decreased temperatures in winter. Anopheles arabiensis is well adapted to high temperatures, since it preferentially breeds in small water bodies in summer (Le Sueur and Sharp, 1988). The snail hosts of human schistosomes have specific requirements in terms of water quality: for instance, Thomas and Tait (1984) and Donnelly and Appleton (1985) noted that they avoid anoxic habitats, a common condition in permanently-inundated zones of wetlands (Malan and Day, 2005). These organisms also respond to temperature which, as noted previously, is a major driver in their distribution (Appleton, 1978). The B. africanus group and Biomphalaria pfeiferri are found in areas where the mean annual air temperature ranges from $15^{\circ} \mathrm{C}$ to $25^{\circ} \mathrm{C}$. There is convincing evidence that the reproductive rates of snails such as Bulinus globosus and Biomphalaria pfeifferi are reduced when the temperature is above $27^{\circ} \mathrm{C}$ and $25^{\circ} \mathrm{C}$ respectively (Shiff and Husting, 1966). Appleton (2006) showed how such high temperatures have determined the distribution of $B$. pfeifferi, and hence $S$. mansoni as well, in north-eastern KwaZulu-Natal. Thus, changes in temperature resulting from alterations in hydraulic conditions may well influence snail distribution.

\section{Changes in water quality}

The influence of some aspects of water quality on IDHs has already been discussed. As noted in Table 3, the anopheline mosquitoes in general seem to prefer fresh, clean water for breeding. This does not mean, however, that maintaining polluted water would necessarily obviate the mosquito problem. Firstly, there is a threat that some Anopheles populations are adapting to polluted urban water sources. Secondly, there is the risk of an explosion in populations of mosquitoes such as Culex quinquefasciatus which breed in polluted water and, whilst not vectoring serious diseases, except in certain circumstances hepatitis B (Fouché et al., 1990), are very much a nuisance factor.

\section{Changes in vegetation}

The effect of vegetation on IDHs is complex. According to Mwangangi et al. (2008), emergent vegetation is known to have a deleterious effect on some mosquito species by obstructing gravid females about to oviposit, and by supporting a greater diversity of aquatic predators. For other species, vegetation can be beneficial, providing protection for their larvae from predators. For example, in Mexico, removal of algal mats from rivers and irrigation canals has led to an effective reduction in malaria by reducing larval habitat (Pepall, 2003). In South Africa, An. funestus is known to prefer to lay eggs in permanent aquatic habitats that are shaded and have emergent vegetation (Table 3). An. arabiensis prefers unvegetated pools during the summer but it overwinters amongst emergent vegetation in permanent water bodies. Thus, increasing the amount of emergent vegetation in a wetland (as may well happen if flow is made more diffuse) is likely to encourage these disease vectors, especially in semi-arid areas where temporary habitats dry out during winter.

Pulmonate snails, including those responsible for schistosomiasis, also prefer habitats with emergent vegetation (Thomas and Daldorph, 1991; Boelee and Laamrani, 2004) although this is not always straight-forward. Floating macrophytes such as Salvinia were found to decrease snail numbers in irrigation canals since their dense growth eliminated submerged macrophytes (although Salvinia mats increased snail numbers in Lake Kariba after it filled). Thomas and Daldorph (1991), working in Nigeria, and Boelee and Laamrani (2004) in Morocco, proposed using dense mats of Salvinia, Pistia or Azolla in water bodies in order to control problem snail populations. While Salvinia and Pistia are native to the northern parts of Africa, they and some subspecies of Azolla are highly invasive in South Africa and so their use in this regard would be problematic.

As noted previously, physico-chemical impacts and biotic responses are inter-related, and changing 1 parameter can have implications for others. For example, the clearing of papyrus from swamps in south-western Uganda (accompanied by some in-filling and cultivation) has resulted in an increased risk of malaria transmission in a region previously at low risk (Lindblade et al., 2000). It is of interest to note here that degradation of a natural wetland has led to an increase in the mosquito problem. This was a consequence of the fact that removal of the natural wetland vegetation led to increased minimum and maximum temperatures, and more favourable mosquito larval habitat. In the rice paddies on the Makathini Flats of north-eastern KwaZuluNatal the temperature regime was buffered more and more as the rice plants grew and shading of the water increased (Appleton, 2006). In this way a thermally inhospitable habitat was rendered hospitable for snails potentially carrying schistosomiasis. 


\section{Biomanipulation and wetland management}

A fairly extensive body of literature exists on the concept of environmental manipulation or modification for the control of mosquitoes (Ault, 1994; Russell, 1999; Keiser et al., 2005; Walker and Lynch, 2007) and schistosome-carrying snails (Thomas and Tait, 1984; Thomas and Daldorph, 1991). Environmental manipulation has been advocated because it is usually less destructive to the environment than using larvicides or molluscicides and, in the case of malaria, avoids the increasing problem of insecticide-resistant vectors. Environmental manipulation methods require a good understanding of the ecology of the pest species and site-specific conditions in order to be effective, however (Russell, 1999; Keiser et al., 2005). In certain scenarios control of schistosomiasis snail hosts has been achieved through removal of vegetation (Boelee and Laamrani, 2004; Thomas and Tait, 1984) but this is not generally recommended. Closer to home, in the 1980s the Durban Municipality used the manual clearing of emergent vegetation from streams within its jurisdiction to control nuisance mosquitoes and at the same time kept snaiI numbers (all species) low for long periods (Gruneberg, 1999). This practice has been discontinued. Recently, Culler and Lamp (2009) advocated the conservation and use of indigenous invertebrate predators such as dytiscid beetles for the control of mosquito larvae in constructed wetlands.

Manipulation of flow has been investigated for control of both snails and mosquitoes (Walker and Lynch, 2007). This aspect is currently being reviewed elsewhere with special reference to rivers (Quayle and Appleton, 2008) and is therefore not repeated here. Instead the focus is on the general characteristics of wetlands that promote mosquito proliferation. This is because, whilst only a limited area of the country is prone to malaria, mosquitoes are a nuisance factor, in terms of biting humans and livestock, country-wide. Furthermore, Walker and Lynch (2007) noted that the popularity and public acceptance of malaria control programmes was limited if only disease vectors were considered rather than if attempts were made to control all nuisance mosquito species. This aspect also needs to be considered when undertaking wetland rehabilitation efforts or constructing artificial wetlands.

Knight et al. (2003) list more than 15 papers giving technical information on how to manage mosquitoes in municipal wastewaters, although such approaches have also been applied to natural wetlands. Papers (e.g. Walton, 2003) and popular articles (e.g. IDNR, 2008) are also available that give general approaches to minimising mosquito abundance. These approaches are discussed below in order to stimulate research in this field. It should be emphasised that critical investigations are required into the applicability of these approaches to the conditions and the pest species found in South Africa. Note that the approaches discussed here apply to freshwater wetlands. Several pest species of mosquito use salt marshes and mud flats as breeding habitat and management techniques for these species (although not specific to South Africa) are discussed in Dale (2007).

The following general characteristics have been found to promote mosquito production in wetlands:

- Shallow water with dense vegetation (Russell, 1999; Knight et al., 2003)

- Areas of standing water

- Newly-flooded habitats with no predators (Russell, 1993 cited in Russell, 1999), especially if located in arid areas (Knight et al., 2003; Karpiscak et al., 2004; Tirados et al., 2006)
- Polluted water, since high levels of organic matter can provide nutrients for the bacteria and algae used as food by mosquito larvae (Walton, 2003); predators may be killed due to poor quality water, and mosquito populations may re-establish themselves faster than other faunal components (Russell, 1999). (This aspect is not directly applicable to anophelines, since they usually prefer clean water).

The following general characteristics have been found to reduce mosquito production in wetlands:

- Open water subjected to wind and wave action, which inhibits larval respiration (Russell, 1999; Walton, 2003)

- Deeper habitats $(>0.6 \mathrm{~m})$ with steep sides that do not support emergent vegetation but do provide habitat for predators, including invertebrates and fish (Service, 1993); the ponds should have a simple shape and low perimeter-toarea ratio; Thullen et al. (2002) suggest controlling excessive plant growth by building small hummocks/islands for emergent vegetation surrounded by deeper water. For a diagram of constructed wetlands in the USA that are designed to minimise mosquitoes, see Walton (2003).

- Subsurface flow, rather than surface water (Russell, 1999)

- Variation in water level can be disruptive to some mosquito species as the larvae can become stranded and desiccated. Constructed wetlands should be designed to have this facility (Russell, 1999). This approach is usually not feasible for natural wetlands, since the aquatic phase of An. arabiensis can be as short as 11 days in summer (Maharaj, 2003).

- Water movement, or generating areas of turbulence in constructed wetlands, for example, by pumping or mechanical aeration (Service, 1993).

- Well-established, more permanently-flooded habitats with established and diverse invertebrate and vertebrate faunas tend to produce relatively few individual mosquitoes (Pont, 2004), although they may support a wide range of mosquito species (Russell, 1993 cited in Russell, 1999).

- Strategic manipulation of vegetation, for example, removal of floating vegetation, may reduce numbers of larvae because they are then more exposed to predators and to wind action (Batzer and Resh, 1994); such an effect is highly dependent on the species of mosquito involved.

\section{Other considerations}

Russell (1999) points out the need to understand aspects of the ecology of mosquitoes additional to breeding habitat preference in order to assess and understand the risk to human communities near a wetland. These aspects include vector behaviour (do they bite at night or during the day, inside or outside?), the flight range, the preferred blood-host (human or non-human?), and the susceptibility of the vector to pathogens. According to Russell (1999), management of mosquitoes is best achieved using an integrated approach designed to make the wetland less suitable for larvae, including manipulation of hydraulic habitat and vegetation, and utilising chemical and biological agents to reduce populations of pest species.

The proximity of human habitation to a wetland is an important consideration in the case of both malaria transmission and schistosomiasis. For afro-tropical malarial vectors, including An. arabiensis and An. funestus, there appears to be a negative correlation between the number of adult mosquitoes found in houses and the distance from larval breeding sites (Minakawa et al., 2002; Minakawa et al., 2004). On investigating the distribution of mosquitoes in a peri-urban area outside 
of Maputo, Mozambique, Mendis et al. (2000) found that further than $350 \mathrm{~m}$ away from breeding sites the number of infective bites per person per year declined sharply. The same author cites various references from different parts of Africa and notes an apparent steep gradient in vector potential over distances as short as 250 to $300 \mathrm{~m}$. Thus whilst human habitation should ideally be situated away from wetlands (Pont, 2004), the distances required appear to be relatively short. This situation does need to be verified for South Africa, however.

It was noted earlier that An. arabiensis can breed in many different types of aquatic habitats (this is also true for $A n$. gambiae s.s but An. arabiensis is the more important vector in this country). It is the habitat created by human activity that may be particularly important in terms of malaria transmission - giving rise to the apt term 'man made malaria' coined by Bruce-Chwatt in 1980. For example, in a recently developed suburban area in the Kenyan highlands, Khaemba et al. (1994 cited in Walker and Lynch, 2007) found temporary pools created through construction activities to be the main breeding sites during the rainy season, whereas permanent dams and, to a lesser extent, natural swamps were important during the dry season. Since this species may breed during the rainy season in pools as small as an inundated hoof-print, increases in vector density may occur independently of wetlands. Increasing the extent of permanent water bodies is likely to provide additional habitat for over-wintering larvae, however. Community education programmes to encourage people to eliminate 'backyard breeding sites' in containers holding stagnant water are important (Pont, 2004). Lindsay et al. (2004) advocate the filling in of abandoned ditches, borrow pits, seepage areas and ponds to reduce mosquito habitat. They also suggest excluding people and livestock from proximity to irrigation dams and canals in order to prevent hoof- and footprints being made. This recommendation is for mosquito control in Asia, but is also likely to be effective in South Africa.

The proximity of human habitation to a wetland is also an important consideration in the transmission of schistosomiasis since Schistosoma requires faeces- or urine-polluted water (and a human host) to complete its life-cycle. The closer a wetland is to human settlements, especially if sanitation is poor, the more likely that the snail hosts in the water will become infected with larval schistosomes. Similar anti-schistosomiasis measures for wetlands are applicable to those developed for irrigation schemes in the 1970s (Pitchford, 1970; Gear and Pitchford, 1977). Thus, where it is unavoidable that people live near wetlands, they should be provided with anti-schistosomiasis measures designed to prevent contact with the water - and thus prevent contamination. These can include alternative facilities for washing clothes, swimming, etc., as well as providing simple bridges over streams and fencing contact points, but this will obviously require a safe, piped water supply as well.

\section{Conclusions}

The objective of this review was to investigate linkages between wetland degradation, rehabilitation and construction and invertebrate disease hosts, and to evaluate the risk to human communities living nearby. A further objective was to stimulate much needed, multi-disciplinary research into this field by reviewing the literature and indicating some of the gaps in our knowledge. We conclude that, in the regions of the country where the diseases are prevalent, there is the potential for wetland rehabilitation or construction (and possibly environmental degradation) to inadvertently encourage the IDHs involved in the transmission of malaria and schistosomiasis. Furthermore, the construction of wetlands for ameliorating water quality, or for any other objective, is irresponsible unless possible deleterious effects on the health of surrounding human populations are taken into account. At the same time, wetlands undoubtedly provide a wealth of benefits, many of which are under-valued or are only recognised once the wetland has been lost. Unfortunately, it would seem that the very characteristics (shallow, slowly-moving water, dense emergent vegetation) required in a wetland to promote, for example, water quality amelioration are the antithesis of the characteristics required for minimising mosquito populations (Russell, 1999; Walton, 2003). Furthermore, increases in disease vectors are often an unforeseen consequence of degradation of ecosystems and naturally-functioning, unimpacted wetlands often provide habitat for fewer pest mosquitoes (Ault, 1994). Thus it is essential that both the potential risks and benefits of wetland modification (in the sense of rehabilitation and conversion or destruction) are considered.

In this review, potential risks of wetland modification to human health were examined by linking the environmental conditions required by IDHs with those likely to occur after wetland modification. Such an approach inevitably involves generalisations in terms of habitat requirement and the abiotic and biotic changes likely to arise from different activities in wetlands. Nevertheless, this is considered to be a useful initial assessment to inform further research. General methods have been presented for minimising IDHs (and, in the case of snails, their infection by schistosomes) by limiting suitable habitat. There is an urgent need for these (and any other techniques that may be identified) to be tested in the South African context. Furthermore, relationships between environmental parameters and individual IDH species are likely to be highly site-specific and detailed case studies are required. The initial research focus should be on the IDHs involved in the transmission of malaria and schistosomiasis. Links between wetlands and the less well-studied diseases (e.g. fascioliasis and arbovirus infections) in humans and stock animals then need to be explored. For instance, whether or not there is any risk of Fasiola infection in people harvesting and eating the fruits of the water chestnut Trapa natans on the Pongolo floodplain, and the breeding biology of the wetland culicine mosquitoes that transmit arboviruses. Examples of arboviruses that are pathogenic to people and/or domestic stock are Rift Valley fever transmitted by Culex theileri and West Nile virus transmitted by C. univittatus (Jupp, 2005). Similarly the biology of the biting midges (Ceratopogonidae), which are widely distributed in South Africa and which are responsible for the transmission of blue tongue disease in sheep and African horse sickness, is poorly known (Picker, 2008). The larvae of many species of biting midge develop in water bodies, and yet virtually nothing is known about the larval habits of the South African species of this group. Both diseases have important economic implications. Finally, the mosquito Mansonia uniformis, which is particularly common in the Richards Bay area (Appleton and Sharp, 1985), is well known as a nuisance species and is probably the most bloodthirsty mosquito in Africa. Its biology is important since the larvae obtain their oxygen from the tissues of submerged plants. This makes them more difficult to control (and find) than those which use atmospheric oxygen.

In the case of malaria in South Africa, it has been claimed that there is too much reliance on interior spraying of houses with DDT (Wells and Leonard, 2006). The use of DDT for malaria control in South Africa was terminated in 1996 but 
reintroduced on a limited scale in 2000 (Attaran and Maharaj, 2000). Little DDT is being sprayed today and this use is temporary, in accordance with an agreement between the Ministry of Health and WHO (Liroff, 2000). This is both to minimise the impacts of insecticides, including DDT, on the environment and to avoid the very serious problem of increasing resistance of mosquitoes to insecticides (Hargreaves et al., 2000; Hargreaves et al., 2003; Gericke et al., 2003; Mouatcho et al., 2009). Methods of environmental control to minimise IDHs should be encouraged (Ramsar, 2008b) and a focused research programme carried out to support this approach. Attaran and Maharaj (2000) drew attention to the fact that what is called 'integrated vector management' has so far enjoyed little practical support in South Africa and remains experimental. This needs to change.

At the same time there has been a marked lack of communication between resource development engineers, health officials and freshwater ecologists (Ramsar, 2008b), which has led in some cases to unacceptable social burdens of schistosomiasis resulting from water resource development (Davies and Day, 1998; Ofoezie, 2002). Lessons have been painfully learnt, but it is vital that these lessons be remembered and implemented in each wetland intervention that takes place in this country. Ault (1994) stresses the need for social scientists to be involved in integrated vector control strategies and Dale and Knight (2008) call for better communication between wetland managers and those involved in managing mosquitoes. We support that call (indeed attention to this need was noted by one of these authors (Appleton, 1983) as far back as the earlier 1980s).

Thus, assessment of the potential risks and benefits of a proposed wetland modification needs to be undertaken in a holistic manner using an adaptive framework that recognises the critical need to balance health, both human and environmental (Dale and Knight, 2008). The adaptive framework should be site-specific, multidisciplinary and take into account the variability: of the habitat requirements of the IDHs, of the presence of disease in human populations and of the ecological functioning of wetlands. It is essential that the full range of social, ecological and hydrological benefits and costs of wetlands are considered, rather than focusing on any one in isolation from the others. There will frequently be trade-offs in maximising one beneficial ecosystem service or minimising a social cost of a particular wetland, and these all need to be taken into account in decision-making processes. For example, while draining wetlands or leaving them in degraded condition might initially appear to be the easiest solution to localised public health threats posed by IDHs, the loss of beneficial ecosystem services provided by these wetlands, such as water purification, flood control, or provision of food and fibre, and their contributions to human health and well-being, also need to be considered. This aspect was emphasised by the 2008 Conference of the Contracting Parties to the Ramsar Convention on Wetlands, which called upon countries to 'ensure that any disease eradication measures in or around wetlands are undertaken in ways that do not unnecessarily jeopardise the maintenance of the ecological character of the wetlands and their ecosystem services' (Ramsar, 2008b). Whilst wetlands can be associated with an increased incidence of globally significant and locally important infectious diseases (such as malaria and schistosomiasis), the removal of wetlands or alteration of their water regimes is not the only disease management option that should be considered. The incidence of many of these diseases can instead be reduced through provision of clean water, improved sanitation, and - importantly - good management of wetlands. In order to assess the potential risks and benefits holistically a multi-disciplinary approach will be required engaging entomologists, health care officials, wetland scientists, sociologists and economists. Whilst this approach is likely to increase the complexity and cost of wetland rehabilitation or construction in the short-term, this is likely to be far outweighed by the long-term savings in public-health costs and the economic benefits provided by wetlands.

\section{Acknowledgements}

This study falls under Phase II of the National Wetlands Research programme. The authors would like to thank the Water Research Commission for funding this study. Especial thanks to Leo Quayle and Chris Dickens (Institute of Natural Resources) for letting us make use of their unpublished work.

\section{References}

APPLETON CC (1975) The influence of stream geology on the distribution of the bilharzia host snails, Biomphalaria pfeifferi and Bulinus (Physopsis) sp. Ann. Trop. Med. Parasitol. 69 241-255.

APPLETON CC (1978) Review of literature on abiotic factors influencing the distribution and life cycles of Bilharzia's intermediate host snails. Malacol. Rev. 11 1-25.

APPLETON CC (1983) Wetlands and public health. J. Limnol. Soc. S. Afr. 9 117-122.

APPLETON CC (2006) Do rice paddies provide a route for the introduction of intestinal schistosomiasis into north-eastern KwaZuluNatal, South Africa? In: Madsen H and Appleton CC (eds.) Proc. Workshop on African Freshwater Malacology. 9-12 September 2003, Kampala, Uganda, DBL Institute for Health Research \& Development. 79-104.

APPLETON CC and SHARP BL (1985) A preliminary study on the emergence of Mansonia uniformis (Diptera: Culicidae) from swamps at Richards Bay, Natal, South Africa. J. Entomol. Soc. S. Afr. 48 179-184.

APPLETON CC, SHARP BL and LE SUEUR D (1995) Wetlands and water-related parasitic diseases of man in Southern Africa. In: Cowan GI (ed.) Wetlands of South Africa. Department of Environmental Affairs and Tourism, Pretoria, South Africa. 227-246.

APPLETON CC and STILES G (1976) Geology and geomorphology in relation to the distribution of snail intermediate hosts of bilharzia in South Africa. Ann. Trop. Med. Parasitol. 70 189-198.

ATTARAN A and MAHARAJ R (2000) DDT for malaria control should not be banned. Br. Med. J. 321 1403-1404.

AWOLOLA TS, ODUOLA AO, OBANSA JB, CHUKWURAR NJ and UNYIMADU JP (2007) Anopheles gambiae s.s. breeding in polluted water bodies in urban Lagos, southwestern Nigeria. J. Vector Dis. 44 241-244.

AULT SK (1994) Environmental management: a re-emerging vector control strategy. Am. J. Trop. Med. Hyg. 50 35-49.

BATZER DP and RESH VH (1994) Wetland management strategies, waterfowl habitat management, and mosquito control. In: Mitsch WJ (ed.) Global Wetlands: Old World and New. Elsevier Science, The Netherlands. 825-832.

BLABER SJM, HAY DG, CYRUS DP and MARTIN TJ (1984) The ecology of two degraded estuaries on the north coast of Natal, South Africa. S. Afr. J. Zool. 19 224-240.

BOELEE E and LAAMRANI H (2004) Environmental control of schistosomiasis through community participation in a Moroccan oasis. Trop. Med. Int. Health 9 (9) 997-1004.

BROWN DS (1966) On certain morphological features of Bulinus africanus and B. globosus (Mollusca: Pulmonata) and the distribution of these species in south-eastern Africa. Ann. Natal Mus. 18 401-415.

BROWN DS (1994) Freshwater Snails of Africa and their Medical Importance. Taylor and Francis, London, UK. 609 pp. 
BRUCE-CHWATT L (1980) Essential Malariology. William Heinemann Medical Books, London, UK. 354 pp.

CDC (2007) Yellow fever fact sheet. Department of Health and Human Services, Centers for Disease Control and Prevention. URL: www. cdc.gov/ncidod/dvbid/yellowfever/YF FactSheet.html (Accessed January 2009).

CDC (2008a) Paragonimiasis. Department of Health and Human Services, Centers for Disease Control and Prevention. Available from: www.dpd.cdc.gov/dpdx/HTML/paragonimiasis (Accessed January 2009).

CDC (2008b) Dengue fever fact sheet. Department of Health and Human Services, Centers for Disease Control and Prevention. URL: www.cdc.gov/ncidod/dvbid/dengue (Accessed January 2009).

CHITSULO L, ENGELS D, MONTRESOR A and SAVIOLI A (2000) The global status of schistosomiasis and its control. Acta Trop. 77 41-51.

COOPPAN RM, NAIDOO K and ISHWARLALL J (1987) Renal function in urinary schistosomiasis in the Natal province of South Africa. Am. J. Trop. Med. Hyg. 37 556-561.

CULLER LE and LAMP WO (2009) Selective predation by larval Agabus (Coleoptera: Dytiscidae) on mosquitoes: support for conservation-based mosquito suppression in constructed wetlands. Freshwater Biol. 54 2003-2014.

DALE PER (2007) Assessing impacts of habitat modification on a subtropical salt marsh: 20 years of monitoring. Wetlands Ecol. Manage. 16 (1) 77-87.

DALE PER and KNIGHT JM (2008) Wetlands and mosquitoes: a review. Wetlands Ecol. Manage. 16 (4) 255-276.

DAVIES B and DAY J (1998) Vanishing Waters. University of Cape Town Press, Cape Town, South Africa. 487 pp.

DEAT (2006) South Africa Environment Outlook: A report on the State of the Environment. Department of Environmental Affairs and Tourism, Pretoria, South Africa. $371 \mathrm{pp}$.

DE KOCK KN and WOLMARANS CT (2005) Distribution and habitats of the Bulinus africanus species group, snail intermediate hosts of Schistosoma haematobium and S. mattheei in South Africa. Water SA 31 (1) 117-125.

DOH (2008) The prevalence and distribution of malaria in South Africa. Statistical Notes, March 2008, Department of Health. URL: http://www.doh.gov.za/docs/stats malaria-f.html (Accessed January 2009).

DONNELLY FA and APPLETON CC (1985) Observations on the field transmission dynamics of Schistosoma mansoni and S. mattheei in southern Natal, South Africa. Parasitol. 91 281-290.

DUFFIELD R and HILL B (2002) Swamp management guidelines for the Fleurieu Peninsula. Conservation Council of South Australia, Adelaide. URL: www.wetlandcare.com.au (Accessed August 2007).

DUGAN PJ (1990) Wetland Conservation: A Review of Current Issues and Required Action. IUCN, Gland, Switzerland.

DURRHEIM DN, GOVERE JM, BRAACK LEO, GERICKE, J and SPEARE R (2001) Malahlapanga - exploiting nature's bounty for malaria control. In: Canyon DV and Speare RS (eds.) Rural and Remote Environmental Health. The Australasian College of Tropical Medicine, Townsville. URL: http://www.tropmed.org reh/voll 12.htm (Accessed October 2008)

FOUCHÉ A, CREWE RM, WINDSOR IM and KARIM SS (1990) Persistence of hepatitis B antigen in Culex quinquefasciatus (Diptera: Culicidae). J. Med. Entomol. 27 697-700.

GEAR JHS and PITCHFORD RJ (1977) Bilharzia in South Africa. Department of Health, Pretoria. $36 \mathrm{pp}$.

GEAR JHS, PITCHFORD RJ and VAN EEDEN JA (1980) Atlas of Bilharzia in South Africa. Joint publication of the South African Institute for Medical Research, South African Medical Research Council and Department of Health. Johannesburg.

GERICKE A, GOVERE JM and DURRHEIM DN (2003) Insecticide susceptibility in the South African malaria mosquito Anopheles arabiensis (Diptera: Culicidae). S. Afr. J. Sci. 98 205-208.

GILLIES MT and DE MEILLON B (1968) The Anophelinae of Africa south of the Sahara. Pub. S. Afr. Inst. Med. Res. 54 1-343.
GIMNIG JE, OMBOK M, KAMAU L and HAWLEY WA (2001) Characteristics of larval Anopheline (Diptera: Culicidae) habitats in Western Kenya. J. Med. Entomol. 38 (2) 282-288.

GRUNEBERG JA (1999) Environmental management for snail control: a perspective from the City of Durban. Presentation to the Parasite Control Task Group, Durban City Council, March 1999. 6 pp.

HAMER ML and APPLETON CC (1991) Physical and chemical characteristics and phyllopod fauna of temporary pools in north-eastern Natal, Republic of South Africa. Hydrobiol. 212 95-104.

HARGREAVES K, HUNT RH, BROOKE BD, MTHEMBU J, WEETO MM, AWOLOLA TS and COETZEE M (2003) Anopheles arabiensis and An. quadriannulatus resistance to DDT in South Africa. Med. Vet. Entomol. 17 417-422.

HARGREAVES K, KOEKEMOER LL, BROOKE BD, HUNT RH, MTHEMBU J and COETZEE M. (2000) Anopheles funestus resistant to pyrethroid insecticides in South Africa. Med. Vet. Entomol. 14 181-189.

HEEG J (1975) A note on the effects of drastic changes in total dissolved solids on the aquatic snail Bulinus (Physopsis) africanus Krauss. J. Limnol. Soc. S. Afr. 1 29-32.

IDNR (INDIANA DEPARTMENT OF NATURAL RESOURCES, USA) (2008) Indiana Wetlands Conservation Plan. Did you know ... healthy wetlands devour mosquitoes? Indiana Department of National Resources. URL: http://www.nae.usace.army.mil/reg mosquitoes.pdf (Accessed December 2008).

IMPOINVIL DE, KEATING J, MBOGO CM, POTTS MD, CHOWDHURY RR and BEIER JC (2008) Abundance of immature Anopheles and culicines (Diptera: Culicidae) in different water body types in the urban environment of Malindi, Kenya. J. Vector Ecol. 33 (1) 107-116.

JOUBERT PH, PRETORIUS SJ, DE KOCK KN and VAN EEDEN JA (1984) The effect of constant low temperatures on the survival of Bulinus africanus (Krauss), Bulinus globosus (Morelet) and Biomphalaria pfeifferi (Krauss). S. Afr. J. Zool. 19 314-316.

JOUBERT PH, PRETORIUS SJ, DE KOCK KN and VAN EEDEN JA (1986) Survival of Bulinus africanus (Krauss), Bulinus globosus (Morelet) and Biomphalaria pfeifferi (Krauss) at constant high temperatures. S. Afr. J. Zool. 21 85-88.

JUPP PG (2005) Mosquitoes as vectors of human disease in South Africa. S. Afr. Fam. Pract. 47 (9) 68-72.

KADLEC RH and KNIGHT RL (1996) Treatment Wetlands. CRC Lewis Publishers, Boca Raton, Florida, USA, 893 pp.

KARPISCAK MM, KINGSLEY KJ, WASS RD, AMALFI FA, FRIEL J, STEWART AM, TABOR J and ZAUDERER J (2004) Constructed wetland technology and mosquito populations in Arizona. J. Arid Environ. 56 681-707.

KEATING K, MACINTYRE K, MBOGO C, GITHEKO A, REGENS JL, SWALM C, NDENGA B, STEINBERG LJ, KIBE L, GITHURE JI and BEIER J (2003) A geographic sampling strategy for studying relationships between human activity and malaria vectors in urban Africa. Am. J. Trop. Med. Hyg. 68 (3) 357-365.

KEISER J, SINGER BH and UTZINGER J (2005) Reducing the burden of malaria in different eco-epidemiological settings with environmental management: a systematic review. Lancet Infect. Dis. 5 695-708.

KENGNE ID, BRISSAUD F, AKOA A, ETEME RA, NYA J, NDIKEFOR A and FONKOU T (2003) Mosquito development in a macrophyte-based wastewater treatment plant in Cameroon (Central Africa). Ecol. Eng. 21 (1) 53-61.

KHAEMBA BM, MUTANI A and BETT MK (1994) Studies of anopheline mosquitoes transmitting malaria in a newly developed highland urban area: a case study of Moi University and its environs. East Afr. Med. J. 71 (3) 159-164.

KNIGHT RL, WALTON WE, O'MEARA GF, REISEN WK and WASS R (2003) Strategies for effective mosquito control in constructed treatment wetlands. Ecol. Eng. 21 211-232.

KOENRAADT CJM, GITHEKO AK and TAKKEN W (2004) The effects of rainfall and evapotranspiration on the temporal dynamics of Anopheles gambiae s.s and Anopheles arabiensis in a Kenyan village. Acta Trop. 90 141-153.

KOTZE DC, BREEN CM and QUINN N (1995) Wetland losses in South Africa. In: Cowan GI (ed.) Wetlands of South Africa. 
Department of Environment Affairs and Tourism, Pretoria, South Africa. 263-272.

KOTZE D, MARNEWECK G, BATCHELOR A, LINDLEY D and COLLINS N (2008a) WET-Ecoservices: A Technique for Rapidly Assessing Ecosystem Services Supplied by Wetlands. WETManagement Series. WRC Report No. TT 339/08, Water Research Commission, Pretoria, South Africa. 80 pp.

KOTZE DC, ELLERY WN, ROUNTREE M, GRENFELL MC, MARNEWECK GC, NXELE SI, BREEN C, DINI J, BATCHELOR AL and SIEBEN, E (2008b) WET-RehabPlan: Guidelines for Planning Wetland Rehabilitation in South Africa. WETManagement Series. WRC Report No. TT 336/08. Water Research Commission, Pretoria, South Africa. $61 \mathrm{pp}$

KVALSVIG JD (2003) Parasites, nutrition, child development and public policy. In: Crompton DWT, Montresor A, Nesheim MC and Savioli L (eds.) Controlling Disease Due to Helminth Infections. World Health Organization, Geneva. 55-65.

KVALSVIG JD and SCHUTTE CHJ (1986) The role of human water contact patterns in the transmission of schistosomiasis in an informal settlement near a major industrial area. Ann. Trop. Med. Parasitol. 80 13-26.

LANGONE J (2008) Protecting yourself against malaria is imperative on a trip to southern Africa. Here's what you should know. ThirdWorld traveller. URL: h ttp://www.thirdworldtraveler.com/Disease/ malaria SouthernAfrica (Accessed August 2008).

LE SUEUR D (1993) Personal communication. Medical Research Council, Durban, South Africa.

LE SUEUR D and SHARP BL (1988) The breeding requirements of three members of the Anopheles gambiae Giles complex (Diptera: Culicidae) in the endemic malaria area of Natal, South Africa. Bull. Entomol. Res. 78 549-560.

LINDBLADE KA, WALKER ED, ONAPA AW, KATUNGU J AND WILSON M (2000) Land use change alters malaria transmission parameters by modifying temperature in a highland area of Uganda. Trop. Med. Int. Health 5 (4) 263-274.

LINDSAY SW, PARSON L and THOMAS CJ (1998) Mapping the ranges and relative abundance of the two principal African malaria vectors, Anopheles gambiae sensu stricto and An. arabiensis, using climate data. Proc. R. Soc. Lond., Ser. B: Biol. Sci. 265 847-854.

LINDSAY S, KIRBY M, BARIS E and BOS R (2004) Environmental management for malaria control in East Asia and Pacific region. The World Bank health, nutrition and population (HNP) discussion paper. Washington DC 20433, USA. 46 pp.

LIROFF R (2000) Reduction and elimination of DDT should proceed slowly. Br. Med. J. 321 1404-1405.

MAHARAJ R (2003) Life table characteristics of Anopheles arabiensis (Diptera: Culicidae) under simulated seasonal conditions. J. Med. Entomol. 40 (6) 737-742.

MAHARAJ R, MTHEMBU DJ and SHARP BL (2005) Impact of DDT re-introduction on malaria transmission in KwaZulu-Natal. $S$. Afr. Med. J. 95 871-874.

MALAN HL and DAY JA (2002) Linking Discharge, Water Quality and Biotic Response in Rivers: A Literature Review. WRC Report No. 956/2/02, Water Research Commission, Pretoria, South Africa. pp. 132.

MALAN HL and DAY JA (2005) Wetland Water Quality and The Ecological Reserve. WRC Report No. 1311/1/05. Water Research Commission, Pretoria, South Africa. pp. 214

MALTBY E, HOGAN DV, IMMIRZI CP, TELLAM JH and VAN DER PEIJL MJ (1994) Building a new approach to the investigation and assessment of wetland ecosystem functioning. In: Mitsch WJ (ed.) Global Wetlands, Old World and New. Elsevier Press, The Netherlands. pp. 637-658.

MATTHEWS S and BRAND K (2004) Africa Invaded: The Growing Danger of Invasive Alien Species. Global Invasive Species Programme, Cape Town, 79 pp.

MCINTOSH BM, RUSSELL D, DOS SANTOS E and GEAR JL (1980) Rift Valley fever in humans in South Africa. S. Afr. Med. J. 58 803-806.

MENDIS C, JACOBSEN JL, GAMAGE-MENDIS A, BULLE E, DGEDGE M, THOMPSON R, CUAMBA N, BARRETO J, BEGTRUP K, SINDEN RE and HOGH B (2000) Anopheles arabiensis and An. funestus are equally important vectors of malaria in Matola coastal suburb of Maputo, southern Mozambique. Med. Vet. Entomol. 14 171-180.

MILLENNIUM ECOSYSTEM ASSESSMENT (2005) Ecosystems and Human Well-being: Synthesis. Island Press, Washington DC. $137 \mathrm{pp}$.

MILLER JR, HUANG J, VULULE J and WALKER ED (2007) Life on the edge: African malaria mosquito (Anopheles gambiae s.l.) larvae are amphibious. Naturwissenschaften 94 (3) 195-199.

MINAKAWA N, SEDA P and YAN G (2002) Influence of host and larval habitat distribution on the abundance of African malaria vectors in Western Kenya. Am. J. Trop. Med. Hyg. 67 (1) 32-38.

MINAKAWA N, SONYE G, MOGI M AND YAN G (2004) Habitat characteristics of Anopheles gambiae s.s. larvae in a Kenyan highland. Med. Vet. Entomol. 18 301-305.

MOODLEY I, KLEINSCHMIDT I, SHARP B, CRAIG M and APPLETON C (2003) Temperature-suitability maps for schistosomiasis in South Africa. Ann. Trop. Med. Parasitol. 97 617-627.

MOUATCHO JC, MUNHENGA G, HARGREAVES K, BROOKE BD, COETZEE M and KOEKEMOER LL (2009) Pyrethroid resistance in a major African malaria vector Anopheles arabiensis from Mamfene, northern KwaZulu-Natal, South Africa. S. Afr. J. Sci. 105 127-131.

MRC (2007) Malaria in Southern Africa. Malaria Research Programme, Medical Research Council, South Africa. URL: www.malaria.org.za (Accessed July 2009).

MUTERO CM, BLANK H, KONRADSEN F and VAN DER HOEK $\mathrm{W}$ (2000) Water management for controlling the breeding of Anopheles mosquitoes in rice irrigation schemes in Kenya. Acta Trop. 76 253-263.

MUTERO CM, NG'ANG'A PN, WEKOYELA P, GITHURE J and KONRADSEN F (2004). Ammonium sulphate fertiliser increases larval populations of Anopheles arabiensis and culicine mosquitoes in rice fields. Acta Trop. 89 187-192.

MWANGANGI JM, MUTURI EJ, SHILILU J, MURIU JS, JACOB B, KABIRU EW, MBOGO CM, GITHURE J and NOVAK R (2008) Contribution of different aquatic habitats to adult Anopheles arabiensis and Culex quinquefasciatus (Diptera: Culicidae) production in a rice agroecosystem in Mwea, Kenya. J. Vector Ecol. 33 (1) $129-138$.

OFOEZIE IE (2002) Human health and sustainable water resources development in Nigeria: Schistosomiasis in artificial lakes. Nat. Resour. Forum, UN 26 (2) 150-160.

PEPALL J (2003) Case study - health, an ecosystem approach: Malaria and agriculture in Kenya - a new perspective on the links between health and ecosystems. Ecosystem Approaches to Human Health Program Initiative, International Development Research Centre, Canada. URL: www.idrc.ca/ecohealth (Accessed July 2008).

PICKER M (2008) Personal communication, 3 July 2008. Department of Zoology, University of Cape Town, Cape Town, South Africa.

PITCHFORD RJ. (1970) Control of bilharziasis by rural management. Central Afr. J. Med. 16 31-33.

POFF NL, BRINSON MM and DAY JW (2002) Aquatic Ecosystems and Global Climate Change: Potential Impacts on Inland Freshwater and Coastal Wetland Ecosystems in the United States. Prepared for the Pew Center on Global Climate Change.

PONT D (2004) Mosquitoes and wetlands on the NSW North Coast. Short discussion paper by a wetland designer. URL: http://www. ecotechgroup.com/downloads/Mosquitos\%20and\%20Wetlands.doc (Accessed January 2008).

PRETORIUS SJ, JOUBERT PH and DE KOCK KN (1989) A review of the schistosomiasis risk in South African dams. Water $S A \mathbf{1 5}$ 133-136.

QUAYLE LM and APPLETON CC (2008) The effects of stream flow manipulation on the intermediate hosts and vector populations of disease and the transmission of the associated parasites. 31 March 2008. Final report presented to the Steering Committee for WRC Project No. K5/1589 on 11 June 2008.

RAMSAR (1971) Convention on wetlands of international importance especially as waterfowl habitat. UN Treaty Series No. 14583.

RAMSAR (2008a) Healthy wetlands, healthy people - a review of wetlands and human health interactions. URL: http://www.ramsar. 
org/cop10/cop10 doc28 e.pd (Accessed July 2009).

RAMSAR (2008b) Resolution X.23. Wetlands and human health and well-being. $10^{\text {th }}$ Meeting of the Conference of the Parties to the Convention on Wetlands (Ramsar, Iran 1971). URL: http://www. ramsar.org/res/key res x 23 e.pd (Accessed July 2009).

RAPPOLE JH, DERRICKSON SR and HUBÁLEK Z (2000) Migratory birds and spread of West Nile Virus in the Western Hemisphere. Emerging Infect. Dis. 6 (4) 319-328.

RUSSELL RC (1993) Mosquitoes and Mosquito-borne Disease in Southeastern Australia. (Revised edn). Department of Medical Entomology, Westmead Hospital, Westmead, Australia. 320 pp.

RUSSELL RC (1998) Mosquito-borne arboviruses in Australia: the current scene and implications of climate change for human health. Int. J. Parasitol. 28 955-969.

RUSSELL RC (1999) Constructed wetlands and mosquitoes: health hazards and management options - an Australian perspective. Ecol. Eng. 12 107-124.

SERVICE MW (1993) Mosquito Ecology: Field Sampling Methods $\left(2^{\text {nd }}\right.$ edn.) Elsevier, New York. 988 pp.

SERVICE MW and TOWNSEND H (2002) The Anopheles vector. In Warrell DA and Gilles HM (eds.) Essential Malariology (4 ${ }^{\text {th }}$ edn.) Arnold Publishers, U.K. pp. 85-106.

SHEARER H (1997) Rennies Wetland Project: Western Cape region Stage 1. Prepared for Wildlife and Environment Society, Western Cape, PO Box 90145, Tokai.

SHIFF CJ (1964) Studies on Bulinus (Physopsis) globosus in Rhodesia. I. The influence of temperature on the intrinsic rate of natural increase. Ann.Trop. Med. Parasitol. 58 94-105.

SHIFF CJ and GARNETT B (1967) The influence of temperature on the intrinsic rate of natural increase of the freshwater snail Biomphalaria pfeifferi (Krauss). Arch. Hydrobiol. 62 429-438.

SHIFF CJ and HUSTING EL (1966) An application of the concept of intrinsic rate of natural increase to studies on the ecology of freshwater snails of the genera Biomphalaria and Bulinus (Physopsis) in southern Africa. Proc. Trans. Rhodesian Sci. Assoc. 51 1-8.

SWANEPOEL R and KEMP A (2005) Personal communication. National Institute for Communicable Diseases, Johannesburg, South Africa.

TANSER FC, SHARP B and LE SUEUR D (2003) Potential effect of climate change on malaria transmission in Africa. Lancet 362 1792-1798.

THOMAS JD and DALDORPH PWG (1991) Evaluation of bioengineering approaches aimed at controlling pulmonate snails: the effects of light attenuation and mechanical removal of macrophytes. J. Appl. Ecol. 28 (2) 532-546.

THOMAS JD and TAIT AI (1984) Control of the snail hosts of schistosomiasis by environmental manipulation: a field and laboratory appraisal in the Ibadan area, Nigeria. Philos. Trans. R. Soc. Lond. Ser. B: Biol. Sci. 305 (1123) 201-253.

THULLEN JS, SARTORIS JJ and WALTON WE (2002) Effects of vegetation management in constructed wetland treatment cells on water quality and mosquito production. Ecol. Eng. 18 441-457.
TIRADOS I, CONSTANTINI C, GIBSON G and TORR SJ (2006) Blood-feeding behaviour of the malarial mosquito Anopheles arabiensis: implications for vector control. Med. Vet. Entomol. 20 425-437.

TREN R and BATE R (2004) South Africa's war against malaria: lessons for the developing world. Policy Analysis No. 513. Cato Institute, Washington DC

WALKER K and LYNCH M (2007) Contributions of Anopheles larval control to malaria suppression in tropical Africa: review of achievements and potential. Med. Vet. Entomol. 21 2-21.

WALTON WE (2003) Managing mosquitoes in surface-flow constructed treatment wetlands. Division of Agriculture and Natural Resources, University of California, Publication 8117. URL: http:/ anrcatalog.ucdavis.edu (Accessed July 2008).

WANER S (1999) Health risks of travellers in South Africa. J. Travel Med. 6 199-203.

WELLS M and LEONARD L (2006) DDT contamination in South Africa. The International POPs Elimination Project (IPEP): fostering active and effective civil society participation in preparations for implementation of the Stockholm Convention. Prepared by Groundwork, Pietermaritzburg, South Africa. URL: www. Ipen. org (Accessed July 2008).

WHO (2001) Yellow fever factsheet. URL: h ttp://www.who.int/mediacentre/factsheets/fs100/en/ (Accessed Jan 2009).

WHO (2002) Prevention and Control of Schistosomiasis and Soiltransmitted Helminthiasis, Report of a WHO Expert Committee. WHO Technical Report Series 912, Geneva.

WHO (2007) Rift Valley Fever factsheet. URL: http://www.who.int mediacentre/factsheets/fs207/en/ (Accessed September 2008).

WHO (2008a) Dengue and dengue haemorrhagic fever factsheet. URL: http://www.who.int/mediacentre/factsheets/fs117/en/ (Accessed September 2008)

WHO (2008b) Chikungunya factsheet. URL: http://www.who.int mediacentre/factsheets/fs117/en/ (Accessed January 2009).

WHO and UNICEF (2003) Africa malaria report. World Health Organisation/UNICEF, Geneva, Switzerland. 43 pp. URL: http:// www.who.int/malaria/amd2003/ amr2003 (Accessed July 2008).

WHO and UNICEF (2006) Chapter 6: Protecting and Promoting Human Health. In: Water: a shared responsibility. The United Nations World Water Development Report 2. 202-240.

WILLOTT E (2004) Restoring nature, without mosquitoes? Restor. Ecol. 12 (2) 147-153.

WOLMARANS CT, BREMOND P and DE KOCK KN (2005) The occurrence and distribution of schistosome intermediate hosts in relation to the prevalence of schistosome infections in humans in a highly endemic area in the Limpopo Province, South Africa. S. Afr. J. Epidemiol. Infect. 20 (1) 18-22.

WOLMARANS CT, DE KOCK KN, POTGIETER A and POSTMA $S$ (2006) Occurrence of urinary schistosomiasis in the greater Rustenburg area, North West province, an area not typical for endemic bilharzia. S. Afr. J. Sci. 102 246- 249.

ZIMMERMAN R (2001) Wetlands and infectious diseases. Cad. Saúde Pública, Rio de Janeiro 17 (Supplemento) 127-131. 
